WITH THE COMPLIMENTS OF THE IRISH CANCER SOCIETY LTD.

I. J. Med. Science, Vol. 140, No. 5, May, 1971

\title{
SMOKING, DRUGS AND ALCOHOL IN DUBLIN SECONDARY SCHOOLS
}

\author{
A. O'Rourke, K. Wilson-Davis and Cora Gough \\ Royal College of General Practitioners, Economic and Social Research \\ Institute and Irish Cancer Society.
}

\section{Introduction}

In the Spring of 1970 the Irish Cancer Society carried out a repeat survey of the smoking habits of secondary school-children in Dublin as part of its Schools' Health Education Programme. A previous survey had been carried out in 1967. In view of the increasing concern over drug-taking among young children it was decided to include questions on drugs and drinking in the present survey.

Our objects in doing this survey were three-fold; to obtain data on children's current smoking behaviour and to compare this with our previous study; to assess children's attitudes towards smoking with the object in view of designing a better antismoking campaign to obtain base-line data on drink and drug-taking by school-children.

\section{The Sample and Method}

From the Dublin secondary school list a 20 per cent random sample was picked with the probability of selection being proportional to the school attendance. We obtained our information by the use of self completing questionnaires which were distributed to the children in their class rooms by a specially trained interviewer. We tried, where possible, to exclude the teachers from being present at these sessions. The interviewer explained the questionnaire to the children, gave help where necessary and particularly emphasised that the forms were completely anonymous. In fact we found the children to be most co-operative and the questionnaires were extremely well filled.

\section{Smoking Behaviour}

The incidence of smoking in the Dublin survey is compared, in table I, with the incidence in the British surveys. The Dublin survey is unique in that girls were included in the sample, the other surveys studied boys only. In the ensuing presentation a regular smoker is one who smokes at least 1 cigarette per week.

Amongst Dublin boys there is a higher incidence of smoking under 14 years of age. This is particularly evident in the 12 year olds where if we compare our study with that of Brynner we see that 25 per cent of the Dublin boys are regular smokers as compared to 9 per cent in the English sample. Over 14 years of age there is little difference between the samples. Over two-thirds of the boys aged 12 years or under have tried smoking

This article is a reproduction of that published in: Irish Journal of Medical Science, 140(5), May, 1971, pp.230-241. Pagination may not match that of original. 


\section{TABLE I}

Incidence of smoking by age group

\begin{tabular}{|c|c|c|c|c|c|c|c|c|}
\hline \multirow[t]{2}{*}{ Study } & \multirow{2}{*}{$\begin{array}{l}\text { Date of } \\
\text { field } \\
\text { work }\end{array}$} & \multirow[t]{2}{*}{ Sample } & \multicolumn{6}{|c|}{$\begin{array}{c}\text { Percentage of regular smokers } \\
\text { by age }\end{array}$} \\
\hline & & & $\begin{array}{l}11 \& \\
\text { under }\end{array}$ & 12 & 13 & 14 & 15 & $16+$ \\
\hline $\begin{array}{l}\text { Cartwright \& Thompson } \\
\text { (1960) }\end{array}$ & 1959 & $\begin{array}{l}1,578 \text { boys in } 4 \\
\text { Edinburgh Schools }\end{array}$ & & 9 & 16 & 33 & 29 & \\
\hline Tobacco Research & 1961 & 2,340 boys aged & & & & & & \\
\hline Council (1962) & & $\begin{array}{l}10-15 \text { (quota } \\
\text { sample) }\end{array}$ & 3 & 4 & 13 & 20 & 25 & \\
\hline Jeffreys (1967) & 1965 & $\begin{array}{l}56714 \text { yr. old boys } \\
\text { in } 12 \text { Sec. Mod. } \\
\text { (Lond). }\end{array}$ & & & & & 36 & \\
\hline $\begin{array}{l}\text { Holland \& Elliott } \\
\text { (1968) }\end{array}$ & 1965 & $\begin{array}{l}2,409 \text { boys, } .14-15 \\
\text { yr. old Sec Mod } \\
\text { and Grammar }\end{array}$ & & & & & 27 & \\
\hline $\begin{array}{l}\text { Tobacco Research } \\
\text { Council (1966) }\end{array}$ & $1965 / 6$ & $\begin{array}{l}1,944 \text { boys aged } \\
10-15 \text { (random) }\end{array}$ & 5 & 4 & 5 & 16 & 22 & \\
\hline Brynner (1969) & 1966 & $\begin{array}{l}\text { 5,601 boys: } \\
\text { natural sample } \\
\text { England \& Wales }\end{array}$ & 4 & 9 & 17 & 27 & 38 & \\
\hline Dublin Survey (1970) & 1970 & $\begin{array}{l}\text { Random sample } \\
3,015 \text { boys } \\
2,468 \text { girls }\end{array}$ & & 25 & 24 & 33 & 38 & 45 \\
\hline & & aged $11-19$ & & 3 & 9 & 18 & 25 & 28 \\
\hline
\end{tabular}

(table II). An interesting feature in the boys is that while the proportion who smoke regularly increases with age (from 24 per cent of the 13 year olds to 47 per cent of the 18 year olds and over), this increase in regular smokers comes from the group of boys who experiment with smoking-there is no age trend-among the non-smokers. The conclusion is clear-effort must be directed at the experimenters to dissuade them from smoking regularly. Among the girls, a significantly lower proportion smoke at each age than the boys. The increase of regular smoking comes from a decreasing proportion of nonsmokers at each successive age group, this decrease also supplies the increase in experimenters at each age group (table II).

\section{Amount Smoked}

Boys smoke significantly more cigarettes than girls, the difference in the mean being significant at the 1 per cent level. The distributions also differ significantly $\left(\mathrm{X}^{2}\right.$ $=137.4, \mathrm{p}=0.001)$. As table III shows, the girls have a positively skewed distribution whereas the boys show a bimodal distribution with a quarter of them smoking over sixty cigarettes a week. 


\section{TABLE II}

Smoking habit by sex and age

\begin{tabular}{lrrrrrrrr}
\hline \multicolumn{1}{c}{ Boys } & $12 \&$ under & 13 & 14 & 15 & 16 & 17 & $18+$ & Total \\
\cline { 2 - 8 } Percentage of & & & & & & & & \\
Regular Smokers & 25 & 24 & 33 & 38 & 45 & 44 & 47 & 35 \\
Triers & 46 & 49 & 39 & 38 & 33 & 36 & 22 & 40 \\
Never smoked & 29 & 27 & 28 & 24 & 22 & 20 & 31 & 25 \\
\hline Number & 169 & 593 & 736 & 674 & 474 & 316 & 45 & 3,015 \\
\multicolumn{1}{c}{ Girls } & & & & & & & & \\
Percentage of & & & & & & & & \\
Regular smokers & 3 & 9 & 18 & 25 & 28 & 29 & 28 & 18 \\
Triers & 34 & 40 & 42 & 43 & 44 & 45 & 50 & 49 \\
Never smoked & 63 & 51 & 40 & 32 & 28 & 26 & 22 & 40 \\
Number & 282 & 520 & 541 & 475 & 367 & 248 & 32 & 3,468 \\
\hline
\end{tabular}

The totals include 8 boys and 3 girls, ages not stated.

TABLE III

Amount smoked per week by regular smokers of either sex

\begin{tabular}{ccccc}
\hline \multirow{2}{*}{$\begin{array}{c}\text { No. of cigarettes } \\
\text { per week }\end{array}$} & Percentage & Number & Percentage & Number \\
\hline $1-9$ & 15.8 & 168 & 39.5 & 178 \\
$10-19$ & 16.6 & 176 & 20.4 & 92 \\
$20-29$ & 13.5 & 143 & 15.6 & 70 \\
$30-39$ & 11.7 & 124 & 6.7 & 30 \\
$40-49$ & 10.8 & 104 & 4.9 & 22 \\
$50-59$ & 7.1 & 66 & 2.9 & 13 \\
60 and over & 24.5 & 260 & 10.0 & 45 \\
\hline Total & 100 & 1,041 & 100 & 450 \\
\hline
\end{tabular}


The average amount smoked by the boys is 40.4 cigarettes a week and by the girls 23.5 cigarettes a week but these overall figures hide an important age trend. In the boys, the mean number of cigarettes smoked steadily increases from 18.4 cigarettes per week for those 12 years old and under to 59.9 cigarettes per week for those 17 years old and over. In the girls the corresponding figures are 13.5 and 33.2.

\section{TABLE IV}

Comparison between regular smokers, 1967 and 1970 surveys

\begin{tabular}{lccccccccc}
\hline & \multicolumn{1}{c}{ Current age (years) } \\
\cline { 2 - 9 } \multicolumn{1}{c}{$\begin{array}{l}\text { Boys } \\
\text { Percentages }\end{array}$} & $12 \&$ & 13 & 14 & 15 & 16 & 17 & $18+$ & Total \\
under & & & & & & & \\
Regular smoker (1967) & 12.6 & 19.2 & 31.0 & 35.8 & 42.1 & 43.4 & 55.3 & 31.9 \\
Regular smoker (1970) & 24.9 & 23.6 & 33.2 & 37.8 & 45.1 & 43.7 & 46.7 & 35.2 \\
\hline Number (1970) & 169 & 593 & 736 & 674 & 474 & 316 & 45 & 3,015 \\
$\quad$ & & & & & & & & \\
Girls & 1.3 & 6.4 & 11.4 & 12.5 & 14.6 & 21.7 & 20.0 & 10.5 \\
Regular smoker (1967) & 2.8 & 9.2 & 17.9 & 24.6 & 28.1 & 28.6 & 28.1 & 18.4 \\
Regular smoker (1970) & 282 & 520 & 541 & 475 & 367 & 248 & 32 & 2,468 \\
\hline Numbers (1970) & & & & & & & & & \\
\hline
\end{tabular}

The totals include 8 boys and 3 girls, age not stated.

\section{Comparison with previous study}

A comparison between regular smokers in the 1967 and 1970 surveys can be seen in table IV. If we disregard the 18+ age group in the boys, which only surveyed 45 boys, we see that there has been an increase in smoking in all age groups in both boys and girls. In the boys the increase has been small except in the 12 and under age group where the incidence of smoking has doubled. In the girls the picture is a lot gloomier; overall 18.4 per cent of the girls age 12-18 years are now smoking as compared to 10.5 per cent three years ago. The major increase again with the girls is in the lower age groups from 12-16 years. 


\section{Parental Attitudes}

Parental attitudes to their children's smoking habits are demonstrated in table V. They are, of course, the child's interpretation of the parents' attitude. Parental knowledge of their child's smoking is positively correlated with the age of the child. Just over a quarter of the parents of boys aged 12 years or under, who smoke regularly, know of their boy's habit, while over three quarters of the parents of boys aged 16 years realise they smoke. The figures for the girls show that even at older ages, a high proportion of parents do not know that their daughters smoke. Just over half of the parents of girls aged 16 years do not appear to know that their daughters smoke. Parental approval increases with the age of the child, even so over two thirds of the parents do not approve their 17 year old or over smoking. Even where the parents smoke themselves, they disapprove of their children's smoking habits.

\section{TABLE V}

Parental knowledge and approval of children's smoking habit (regular smokers)

\begin{tabular}{|c|c|c|c|c|c|c|c|}
\hline \multirow[b]{2}{*}{ Boys } & \multicolumn{7}{|c|}{ Current age } \\
\hline & $\begin{array}{l}12 \& \\
\text { under }\end{array}$ & 13 & 14 & 15 & 16 & $\begin{array}{l}17 \& \\
\text { over }\end{array}$ & $\begin{array}{c}\text { All } \\
\text { ages }\end{array}$ \\
\hline \multicolumn{8}{|c|}{ Percentages of parents who } \\
\hline do not know & 68 & 56 & 46 & 30 & 22 & 1 & 33 \\
\hline approve & 0 & 9 & 12 & 19 & 22 & 31 & 19 \\
\hline do not approve & 100 & 91 & 88 & 81 & 78 & 69 & 81 \\
\hline \multicolumn{8}{|l|}{ Girls } \\
\hline \multicolumn{8}{|c|}{ Percentages of parents who } \\
\hline do not know & 63 & 85 & 57 & 60 & 49 & 36 & 55 \\
\hline approve & 0 & 0 & 0 & 22 & 17 & 26 & 16 \\
\hline do not approve & 100 & 100 & 100 & 78 & 83 & 74 & 84 \\
\hline
\end{tabular}

Most earlier studies have stressed the importance of parental example as an influence on children's smoking behaviour. The Dublin study found (table VI) that in the girls there was a positive association between parental habit and their daughters habit $\left.\mathrm{X}^{2}=12.78, \mathrm{p}=.005\right)$. Where both parents smoke 23 per cent of the girls smoke compared with 13 per cent where neither parent smokes. Likewise where both parents smoke 36 per cent of their daughters have never smoked compared with 46 per cent of the daughters of non-smoking parents. 
On the other hand there is no positive association in the boys, in fact the association tends to be in the opposite direction. Where both parents smoke 36 per cent of their sons have never smoked compared with 27 per cent where neither parent smokes. Even more surprising is the fact that where both parents smoke only 9 per cent of the boys smoke regularly compared with 30 per cent where neither parent smokes. When the data are reduced to a $2 \times 2$ table with a simple dichotomy of boys smoke/never smoke and parents smoke/neither smoke there is no association between the parental smoking habit and their boys' smoking behaviour $\left(\mathrm{X}^{2}=0.467,40\right.$ per cent $>\mathrm{p}<50$ per cent.

\section{TABLE VI}

Smoking experience analysed by parental smoking habit

\begin{tabular}{|c|c|c|c|c|c|c|c|}
\hline Sex & Smoking expe & & $\begin{array}{l}\text { Both } \\
\text { parents } \\
\text { Smoke } \\
\end{array}$ & $\begin{array}{l}\text { Father } \\
\text { only } \\
\text { smokes }\end{array}$ & $\begin{array}{l}\text { Mother } \\
\text { only } \\
\text { smoke }\end{array}$ & $\begin{array}{l}\text { Neither } \\
\text { smoke }\end{array}$ & Totals \\
\hline$\overline{\text { Boys }}$ & Regular smokers & & 9 & 38 & 31 & 30 & 27 \\
\hline & Triers & per & 55 & 40 & 38 & 43 & 45 \\
\hline & Never smoked & cent & 36 & 22 & 31 & 27 & 28 \\
\hline & Number in each $g$ & & 689 & 865 & 324 & 583 & 2,461 \\
\hline Girls & Regular smokers & & 23 & 18 & 20 & 13 & 18 \\
\hline & Triers & per & 41 & 44 & 37 & 41 & 41 \\
\hline & Never smoked & cent & 36 & 38 & 43 & 46 & 41 \\
\hline & Number in each $g$ & & 729 & 583 & 329 & 687 & 2,328 \\
\hline
\end{tabular}

\section{Health and Smoking}

It is interesting to note in table VII that the vast majority of children recognise that smoking affects health, even 82 per cent of regular smokers thought that smoking was harmful to their health. There is a significant difference at the 1 per cent level in the boys and girls-between those who regularly smoke and those who have never smoked, suggesting that many more non-smokers than smokers think of the harmful affects of cigarettes. 


\section{TABLE VII}

Do you think smoking affects your health?

\begin{tabular}{|c|c|c|c|c|c|c|c|c|}
\hline \multirow{2}{*}{$\begin{array}{l}\text { Numbers and } \\
\text { percentages }\end{array}$} & \multicolumn{4}{|c|}{ Boys } & \multicolumn{4}{|c|}{ Girls } \\
\hline & Yes & No & $\mathrm{DK}$ & Totals & Yes & No & DK & Total \\
\hline Regular & 870 & 169 & 23 & 1,062 & 376 & 72 & 7 & 455 \\
\hline Trier & 82 & 16 & 2 & 100 & 83 & 16 & 1 & 100 \\
\hline \multirow[t]{4}{*}{ Never smoked } & 1,088 & 82 & 25 & 1,195 & 945 & 70 & 16 & 1,031 \\
\hline & 91 & 7 & 2 & 100 & 92 & 7 & 1 & 100 \\
\hline & 686 & 31 & 41 & 758 & 932 & 29 & 21 & 982 \\
\hline & 91 & 4 & 5 & 100 & 95 & 3 & 2 & 100 \\
\hline \multirow[t]{2}{*}{ Totals } & 2,644 & 282 & 89 & 3,015 & 2,253 & 171 & 44 & 2,468 \\
\hline & 88 & 9 & 3 & 100 & 91 & 7 & 2 & 100 \\
\hline
\end{tabular}

\section{Drugs}

As well as eliciting smoking behaviours, a number of questions were asked on drugs and drug-taking. One question was "have you ever been offered what you thought was an addictive drug?" The answers are analysed in table VIII by sex and age of the respondent. Over 9 per cent of the boys and 6 per cent of the girls stated that they had been offered drugs. In both sexes there is a distinct upward trend with age-16 per cent of the boys and 10 per cent of the girls aged 17 years and over having been offered drugs.

\section{TABLE VIII}

Ever offered drugs?

\begin{tabular}{lcccccr}
\hline & \multicolumn{2}{c}{ Under 16 } & \multicolumn{2}{c}{ Over 16 } & \multicolumn{2}{c}{ Total } \\
& Number & per cent & Number & per cent & Number & per cent \\
& & & & & & \\
\hline Boys & 144 & 6.6 & 132 & 15.8 & 276 & 9.2 \\
Girls & 74 & 4.1 & 63 & 9.7 & 137 & 5.6 \\
\hline Total & 218 & 5.5 & 195 & 13.2 & 413 & 7.5 \\
\hline
\end{tabular}


The older children socialise more and frequent places where there is a growing drug culture and therefore have more opportunity than those in younger age groups to be offered drugs. While there is a marked difference in the incidence of boys and girls who had been offered drugs, it is still surprising that 1 in 10 girls of 16 years and over have had this experience.

Table IX indicates that the regular smokers were more prone to come in contact with drugs than the non-smokers. It is known that smokers tend to favour those leisure activities where they go out and meet other people whereas the non-smokers tend to favour more solitary activities such as reading, watching television and so on (Brynner, 1969). Consequently when the data on being offered a drug are analysed by smoking behaviour, it is seen that of the boys who had been offered a drug 64 per cent were regular smokers and only 8 per cent had never smoked. The corresponding figures for the girls are 56 per cent and 10 per cent respectively.

TABLE IX

Those offered drugs and smoking habit

\begin{tabular}{lcc}
\hline Smoking habit & Boys & Girls \\
\hline Regular & 64 per cent & 56 per cent \\
Trier & 28 per cent & 37 per cent \\
Never & 8 per cent & 7 per cent \\
\hline Numbers offered drugs & 276 & 138 \\
\hline
\end{tabular}

The type of drug offered and taken is indicated in table X. By far the most common drug stated was cannabis. It is still surprising that 38 of the children named L.S.D. and indeed 26 stated that they had been offered hard drugs, in the form of heroin, opium and morphine. We must stress that this is entirely the opinion of the children.

Included in the "other drugs" are such items as shoe conditioner and the mixture of aspirin and coke. The figures in table $\mathrm{X}$ relate to the first drug mentioned as 19 children mention that they had taken 2 drugs.

When asked "Did you ever take drugs?" 2 per cent of the sample replied in the affirmative $(134$ of 5,483). The data are presented by an age and sex breakdown in table XI. The total number of drug takers-134-is surprisingly high considering that our sample is of the school-going population. This would indicate that some 600 - 700 secondary school children have already been experimenting with drugs. 7 per cent of the boys and 8 per cent of the girls stated that they had attended a party where drugs were being taken. 


\section{TABLE X}

Type of drug offered and taken

\begin{tabular}{lcccc}
\hline \multicolumn{1}{c}{ Drug } & \multicolumn{2}{c}{ Boys } & \multicolumn{2}{c}{ Girls } \\
& offered & taken & offered & taken \\
\cline { 2 - 5 } $\begin{array}{l}\text { Marijuana (cannabis), } \\
\text { hash, etc. }\end{array}$ & 85 & 45 & 57 & 33 \\
L.S.D. & 24 & 10 & 14 & 5 \\
Pep Pills & 20 & 8 & 4 & 2 \\
Heroin & 13 & 5 & 5 & 2 \\
Morphine/Opium & 6 & 4 & 2 & 0 \\
Barbiturates & 4 & 3 & 2 & 2 \\
Cocaine & 1 & 0 & 0 & 0 \\
Other & 5 & 3 & 2 & 1 \\
\hline Total mentions & 158 & 78 & 86 & 45 \\
\hline
\end{tabular}

14 boys and 5 girls mentioned two drugs.

TABLE XI

Ever taken drugs? Age and sex.

\begin{tabular}{|c|c|c|c|c|c|c|c|c|}
\hline \multirow{4}{*}{ Boys } & \multirow{4}{*}{$\begin{array}{c}\text { Yes } \\
\text { Percentage }\end{array}$} & \multicolumn{7}{|c|}{$\overline{\text { Age }}$} \\
\hline & & $\begin{array}{l}12 \text { and } \\
\text { under }\end{array}$ & 13 & 14 & 15 & 16 & $17+$ & All \\
\hline & & 0 & 3 & 12 & 18 & 29 & 22 & 84 \\
\hline & & 0 & 1 & 2 & 3 & 6 & 4 & 3 \\
\hline & All boys & 169 & 593 & 736 & 674 & 474 & 361 & 3,015 \\
\hline Girls & Yes & 1 & 4 & 9 & 10 & 12 & 13 & 50 \\
\hline & Percentage & 0 & 1 & 2 & 2 & 2 & 3 & 2 \\
\hline & All girls & 282 & 520 & 541 & 475 & 367 & 280 & 2,468 \\
\hline
\end{tabular}

The totals include 8 boys and 3 girls, age not stated. 
Cannabis was by far the commonest drug taken as shown in table X. It is interesting to note that almost as many girls state they have taken cannabis as boys, 45 out of 3,015 and 33 girls out of 2,468. Eleven of the sample ( 9 boys and 2 girls) stated that they had taken heroin, morphine or opium.

\section{Alcoholic Consumption}

The third part of our questionnaire was devoted to some questions on the use of alcohol. Approximately three quarters of the children have taken alcoholic drink (table XII).

\section{TABLE XII}

Drinking habits by sex

\begin{tabular}{lcccc}
\hline & \multicolumn{2}{c}{ Boys } & \multicolumn{2}{c}{ Girls } \\
& Number & Percentage & Number & Percentage \\
\cline { 2 - 5 } Ever taken a drink & 2,398 & 80 & 1,803 & 73 \\
Are you an abstainer & 1,316 & 44 & 1,269 & 51 \\
Regular drinker & 404 & 13 & 234 & 10 \\
Occasional & Drinker & 1,295 & 43 & 965 \\
\hline
\end{tabular}

Some 13 per cent of all boys and 10 per cent of all girls state that they are regular drinkers. 50 per cent of the girls and 44 per cent of the boys are total abstainers. Four out of ten boys and girls took an occasional drink. XIII.

The total figure for regular drinkers hides a distinct age trend as can be seen in table

\section{TABLE XIII}

Regular drinking by age and sex

\section{Percentage at different ages}

\begin{tabular}{ccccccccccc} 
& $\begin{array}{c}12 \text { and } \\
\text { under }\end{array}$ & 13 & 14 & 15 & 16 & 17 & $\begin{array}{c}18 \text { and } \\
\text { over }\end{array}$ & N.S. & Total & Numbers \\
\hline Boys & 4 & 4 & 8 & 13 & 25 & 29 & 33 & - & 13 & 404 \\
Girls & 4 & 4 & 8 & 10 & 15 & 21 & 25 & - & & 234 \\
\hline
\end{tabular}


We can see that a third of the boys and a quarter of the girls aged 18 years and over state they are regular drinkers. A quarter of boys aged 16 years drink regularly even though it is illegal to serve any person under 18 years with alcoholic drink.

TABLE XIV

Who gave first drink?

\begin{tabular}{lrrrrrr}
\hline \multicolumn{1}{c}{ Boys } & $\begin{array}{l}\text { Regular } \\
\text { drinkers }\end{array}$ & Percentage & Triers & Percentage & Total & Percentage \\
\hline Parent & 105 & 26 & 878 & 45 & 983 & 42 \\
Self & 151 & 37 & 333 & 17 & 484 & 20 \\
Friend & 145 & 36 & 608 & 31 & 753 & 32 \\
Unknown & 1 & 1 & 136 & 7 & 137 & 6 \\
\hline Total & 402 & 100 & 1,955 & 100 & 2,357 & 100 \\
\hline Parent & 135 & 58 & 1,017 & 66 & 1,152 & 65 \\
Self & 17 & 7 & 65 & 4 & 82 & 5 \\
Friend & 77 & 33 & 378 & 24 & 455 & 25 \\
Unknown & 4 & 2 & 88 & 6 & 92 & 5 \\
\hline Total & 233 & 100 & 1,548 & 100 & 1,781 & 100 \\
\hline
\end{tabular}

When asked who gave them their first drink (table XIV) 42 per cent of the boys and 65 per cent of the girls stated it was their parents, 32 per cent of the boys and 25 per cent of the girls said they were given it by a friend.

The difference in drinking habits between all age groups in boys and girls is not as great as might be expected. The figure of 21 per cent of 17 year old girls who stated that they drink regularly seems to us unexpected.

We would like to acknowledge the continuing support of the Irish Cancer Society and particularly the help of its Honorary Director of Information, Dr. Austin Darragh. We particularly appreciate the work of Miss Maureen Groarke who was responsible for the field-work of this survey. We wish to thank the teachers in the schools for their cooperation and help during the survey.

\section{References}

Brynner, J. M. 1969. The Young Smoker (Government Social Survey). London. H.M.S.O.

Cartwright, A., Thompson, J. G. and a group of Edinburgh Ph.D. students. 1960. Young Smokers-an attitude study among school children touching also on parental influence. Brit. J. Prev. and Soc. Med. 14, 28-34. 
Holland, W. W., Elliot, A. 1968. Cigarette smoking, respiratory symptoms and antismoking propaganda. Lancet 1, 41-43.

Jeffreys, M. 1963. Smoking amongst school children, Medical Officer, 109, 19-93.

O’Rourke, A., O’Sullivan, N., Wilson-Davis, K. 1968. A Dublin Schools Smoking Survey: Irish J. med. Sci., 123.

Tobacco Research Council 1962. Statistics of smoking in United Kingdom.

Todd, G. F. 1966. In Statistics of Smoking in United Kingdom, 41h Edition. (Tobacco Research Council). 